\title{
ГEOГPAФИЧECKИE HAYKИ
}

УДК: 314.02 .3 .9

ГЕОГРАФИЯ И НАСЕЛЕНИЯ СЕЛЬСКИХ НАСЕЛЕННЫХ ПУНКТОВ САМАРКАНДСКОЙ

ОБЛАСТИ

\author{
Кадиров Муродилло Асламович \\ Доиент кафедры географии \\ Самаркандского государственного университета, почетный академик АН Туран \\ (Узбекистан) \\ Сафарова Насиба. \\ Студенть \\ Самаркандского государственного университета \\ DOI: 10.31618/ESU.2413-9335.2019.8.60.6-8
}

\section{GEOGRAPHY AND POPULATION OF RURAL SETTLEMENTS OF THE SAMARKAND REGION}

\section{АННОТАЦИЯ.}

В статье проводится география и населения сельских населенных пунктов Самаркандской области на основе ряда статистических показателей, проанализировается состояние сельского расселения и его особенности, выявляется типологии сельских населенных пунктов и т.д.

\section{АННОТАЦИЯ.}

The article deals with the geography and population of rural settlements of the Samarkand region on the basis of a number of statistical indicators, The state of rural settlement and its features are analyzed, typologies of rural settlements and etc.

Ключевые слова: населения сельских населенных пунктов, типология, оазис, горный, пустынный, трудовые ресурсы, новоосвоенные земли, средняя численность населения.

Key words: population of rural settlements, typology, oasis, mountain, desert, work force, newly developed lands, average population.

Введение. Географическое изучение населения всегда занимало центральное место в экономической и социальной географии. Такое положение населения обусловлено тем, что оно является и производителем, и потребителем, созданным им же материальных и духовных благ [1].

Известно, что состояние сельского расселения и его особенности зависят прежде всего от территориальной организации отраслей сельскохозяйственного производства. Сельское население Самаркандской области в основном занимается земледелием, что обслуживает формирование здесь крупных сельских населенных мест. Причем преобладающая часть сельского населения размещена в оазисах. Жители сельской местности в своей территориальной организации тяготеют к водным ресурсам, и поэтому география сельского расселения в высшей степени определяется гидрографической сетью [2]. Развитие и расширение сельских населенных пунктов в значительной степени связано с оросительной сетью, а во внутренней части оазиса на их размещение повлияли также особенности исторического освоения территории. Направление реки Зарафшан с юго-востока области на запад оказывает большое влияние на формирование общего контура расселения сельского населения. При этом более $90 \%$ сельского населения расселено по берегам реки и её притоков. Сельские районы в основном расположены в левобережье. Плотность населения на правобережной части реки Зарафшан составляет более 100 чел., а на левобережной части более 400 чел., что связана также с расположением г. Самарканда [3].
Цель и задачи. Целью исследования является комплексное изучение географии и населении сельских населенных пунктов Самаркандской области на основе ряда статистических показателей. Для этого необходимо решить следующие задачи: 1) проанализировать состояние сельского расселения и его особенности; 2) изучить размещения сельского населения в оазисах, в горных и пустынных районах; 3) исследовать формирование сети СНП в ново освоенных районах; 4) выявить типологии сельских населенных пунктов Самаркандской области.

Результаты и их обсуждение. В Самаркандской области насчитывается 14 сельских районов, 11 городов, 82 городских поселков, 125 кишлачных советов, 1829 сельских населенных пунктов. Часть сельского населения области размещается в горных районах, где в основном занимаются отгонным животноводством. В этих районах сельские поселения размешаются в долинах небольших рек и в межгорных равнинах. Такой характер расселения сельского населения отмечается в Ургутском, Кошрабадском и Самаркандском районах.

Небольшое количество сельского населения размещено в пустынных районах. Они тоже в основном занимаются животноводством и частично земледелием. К таким районам относятся Пахтачийский и Нурабадский районы, где плотность населения сравнительно низкий и составляет 38-40 чел. на кв. км.

Вместе с тем, формируются сеть СНП в новоосвоенных районах. В области таких СНП в основном расположены в Самаркандском и Пастдаргомском районах. 
В рассматриваемых районах имеются малые предприятия, различные фирмы, а также выращиваются сельскохозяйственные продукции. Административный центр Самаркандского района, Гулобод расположен в южной части г.Самарканда. Появление этого поселка на чистом месте связано, прежде всего, с освоением новых земель. В настоящее время в поселке построены жилые коттеджи, совместное предприятие "Блисс", с Россией, который выпускает разные соки, а также расположены кирпичные и бетонные заводы, дневное зона отдыха, в которой расположены несколько бассейнов, универмаг, супермаркет, средние школы, детские сады, организован базар Мароканд и т.д.

Вопросы типологии сельских населенных пунктов, применительно и Средней Азии, были рассмотрены Р.Валиевой, Э.Ташбековым и Г.Р.Асановым, А.Б.Батыровым, М.К.Карахановым, А.Саттаровым и другими. В работах этих авторов выделяются два основных производственных или функциональных типа сельских поселений: сельскохозяйственные и агроиндустриальные.

Указанные типы СНП характерны и для Самаркандской области. При этом, как и везде, численно преобладают сельскохозяйственные типы, которые в свою очередь состоят из следующих подтипов:

1. Села, деревни и поселков центров хозяйств;
2. Центры отдельных хозяйств;

3. Остальные сельскохозяйственные поселения, с функциями жилых поселков;

4. Прочие поселения [4].

Сельскими сельскохозяйственными поселениями считаются $85 \%$ сельские населенные пункты области, 6\% СНП выполняют центры кишлачных советов, 3\% СНП-агропромышленные центры, $0,5 \%$ центры рекреации, а остальные СНП выполняют другие функции.

В Самаркандском области на 1 кв.км территории приходится 214 чел. сельского населения. Самым густонаселенным территориям области, считается территории Самаркандской и Ургутской районов, а к малозаселенной относится юго-западная часть области.

Как сказано, в настоящее время на территории области насчитывается 1829 СНП. Эти СНП по территории области размещены не равномерно. В Пайарикском в Каттакурганском в Иштыханском и в Пастдаргомских районах число СНП больше. В этих районах в среднем расположены по 175 СНП. В Самаркандском, в Тайлякском в Акдарьинском и в Нурабадском районах число СНП мало, в среднем в этих районах размешены по 87 СНП. 1979 году в области число крупных СНП (население более 1000 человек) составлял 286.

Таблица 1 Динамика численности сельского населения области

\begin{tabular}{|l|l|c|c|c|c|}
\hline \multirow{2}{*}{ № } & \multirow{2}{*}{ Район } & \multicolumn{4}{|c|}{ Численности населения (тыс.чел.) } \\
\cline { 3 - 6 } & & 1979 & 1989 & 2007 & 2016 \\
\hline 1. & Акдарьинский & 61,8 & 62,0 & 93,5 & 87,7 \\
\hline 2. & Булунгурский & 52,6 & 73,0 & 114,9 & 132,8 \\
\hline 3. & Джамбайский & 59,5 & 75,5 & 113,0 & 119,9 \\
\hline 4. & Иштиханский & 86,6 & 93,1 & 164,6 & 166,9 \\
\hline 5. & Каттакурганский & 89,5 & 132,2 & 180,0 & 202,8 \\
\hline 6. & Кошрабадский & 77,9 & 83,0 & 97,5 & 108,4 \\
\hline 7. & Нарпайский & 60,8 & 81,6 & 121,1 & 137,0 \\
\hline 8. & Нурабадский & 62,4 & 71,9 & 101,4 & 122,1 \\
\hline 9. & Пайарикский & 95,8 & 101,5 & 162,9 & 160,6 \\
\hline 10. & Пастдаргомский & 98,2 & 151,3 & 232,0 & 237,8 \\
\hline 11. & Пахтачийский & 54,4 & 72,7 & 106,2 & 107,6 \\
\hline 12. & Самаркандский & 81,1 & 277,3 & 269,9 & 218,3 \\
\hline 13. & Тайлякский & - & - & 145,1 & 161,6 \\
\hline 14. & Ургутский & 132,0 & 186,5 & 306,0 & 265,1 \\
\hline 15. & Населения области & 1012,6 & 1461,6 & 2207,9 & 2228,6 \\
\hline
\end{tabular}

Источник: Таблииа составлена автором на базе данных областного статистического управления Самаркандской области

Этот показатель в 1998 году -710, а по последним данным число таких СНП равно более 1000. Крупные СНП в основном расположены в Самаркандском, в Ургутском и в Каттакурганском районах. С быстрым ростом населения СНП выделяются Ургутский, Пайарыкский, Нурабадский и Самаркандский районы. Крупнейшими СНП считается Чандир в Пастдаргомском, Жом в Нурабадском районах.

Сельское население Самаркандской области растет быстрыми темпами. Как показывает таблица
1, в 1979 году среди сельских районов по численности населения выделяются Ургутский и Пайарикский районы. С низкими показателями выделяются Булунгурский и Пахтачийский районы. В 1989 году быстрый рост сельского население наблюдаются в Самаркандском, Пастдаргомском и Каттакурганском районах. В этом году с низким показателем выделяется Акдарьинский и Пайарыкский районы. В то же время, в 2007-году численность населения всех районов увеличились. Только в Самаркандском районе численность населения уменьшилась, это связано с возникновением Тайлякского района. 
Таблица 2. Превращение сельских населенных пунктов Самаркандской области в городских поселений (2015 г.)

\begin{tabular}{|l|c|c|c|}
\hline Наименование районов & Населенные пункты & Численность & Средняя численность населении \\
\hline Акдарынский & 8 & 28172 & 3521 \\
\hline Булунгурский & 3 & 7966 & 2655 \\
\hline Джамбайский & 5 & 16840 & 3368 \\
\hline Иштиханский & 11 & 34455 & 3132 \\
\hline Нарпайский & 2 & 11074 & 5537 \\
\hline Нурабадский & 1 & 4755 & 4755 \\
\hline Пайарикский & 9 & 31146 & 3460 \\
\hline Пастдаргомский & 15 & 51076 & 3405 \\
\hline Пахтачийский & 6 & 14499 & 2416 \\
\hline Самаркандский & 8 & 14318 & 1790 \\
\hline Тайлякский & 7 & 20078 & 2868 \\
\hline Ургутский & 23 & 111286 & 27838 \\
\hline Каттакурганский & 6 & 16590 & 2401 \\
\hline Кошрабадский & 5 & 12004 & \\
\hline
\end{tabular}

Таблииа составлена автором на базе данных областного статистического управления Самаркандской области

В последние годы в численности сельского населения области произошло большое изменения. 2008 году по решению областного хокимията многие крупные сельские населённые пункты превратились в городские поселения. По этому, в некоторых районов области, в том числе в Самаркандском, в Ургутском и в других районах численность сельского население уменьшилась. В Булунгурском и в Каттакурганском районах численность сельского населения увеличилась за счет высокой рождаемости.

Выводы. Проведённый нами географический анализ сельского населения Самаркандской области позволяет сделать следующие выводы.

1. В Самаркандской области по данным 2016 года насчитывается 3583,9 тыс. чел., из них 1355,3 тыс. чел. или 37,8 \% городское население и остальное 2228,6 тыс. чел. или $62,2 \%$ составляет сельское население. Анализы показывает, что сельское население области год за годом увеличилось, но в последние годы доля сельского населения уменьшивается. Как выше отметили это связана с возникновениями многочисленными городскими поселениями.

2. В решении социальных проблем, в улучшении жизни сельского населения велико значение районных центров. В настоящее время правительство Республики Узбекистан предусматривает значительное расширение прав районных властей хокимиятов по организации социальной и экономической жизни на местах. Поэтому сельские район- ные центры должны взять на себя функции по всестороннему обслуживанию хозяйства, населения и его социальных нужд. Для этого необходимо укрепление организующих и обслуживающих функций районных центров и прежде всего, таких как Кошрабад, Нурабад и др.

3. В условиях углубления экономических реформ хокимияти районов и областей будут регулировать размещение предприятий торговли и других отраслей сферы обслуживания с учетом специфических поселений, плотности населения и населённых пунктов. На территории сельских поселений способствует повышению уровню жизни населения, создает условия для полного использования трудовых ресурсов, размещения малых и совместных предприятий и т.д.

\section{Литература:}

1. Анохин А.А., Житин Д.В. География населения с основами демографии. Санкт-Петербург. 2013. 160 стр.

2. Алексеев А.И. Многоликая деревня. М.: Мысль, 1990. 255 стр.

3. Кадиров М.А., Шерхолов О. Самарқанд вилоятида қишлоқ ахоли пунктларининг жойлашиши, ривожланиши ва карталаштириши. //Геодезия, картография ва кадастр сохаларини ривожлантиришнинг долзарб муаммолари. Самарқанд, 2014. -б. 80.

4. Кадиров М.А.Самарқанд вилояти ахоли географияси. Самарқанд. СамДУ, 2017. 150 бет.

5. Статистические материалы Самаркандского областного статистического управления. 
Медеу Ахметкал Рахметуллаевич

Академик НАН РК, директор

Института географии МОН РК,

2. Алматьи

Благовещенский Виктор Петрович

Доктор географических наук, главный научный сотрудник

Института географии МОН РК,

2. Aлматы

Ранова Сандугаш Усеновна

Кандидат географических наук, руководитель лаборатории природных опасностей, Институт географии МОН РК,

2. Алматьв

\section{АННОТАЦИЯ.}

В статье рассматриваются вопросы, связанные с оценкой и картографированием селевой опасности в бассейнах рек Киши и Улкен Алматы. Для оценки селевой опасности рассмотрены такие характеристики как пути движения и границы распространения селей различных объемов и повторяемости. Кроме того, проведено картографирование бассейнов рек Киши и Улкен Алматы на уровне русел и ручьев.

\section{ABSTRACT.}

In the article the questions connected with assessment and mapping of mudflow danger in the river basins of Kishi Almaty and Ulken Almaty are considered. For the assessment of mudflow danger such characteristics as way of flow and limits of distribution of mudflows of different volumes and repeatability are considered. Apart from that, there was completed mapping of river basins of Ulken Almaty and Kishi Almaty at the level of riverbeds and streams.

Ключевые слова: селевая опасность, тип селя, повторяемость, объем, оценка и картографирование селевой опасности

Key words: mudflow danger, mudflow type, repeatability, volume, assessment and mapping of mudflow danger

На карте показаны пути движения и границы распространения селей различных объемов и повторяемости (обеспеченности). По объемам сели разделены на 4 категории: очень крупные с объемом более 1 млн м³, крупные с объемом от 100 тыс. до 1 млн м ${ }^{3}$, средние с объемом от 10 до 100 тыс. м3 мелкие с объемом менее 10 тыс. м³. По повторяемости сели разделены на три градации: частая с повторяемостью чаще 1 раза в 50 лет (обеспеченность более $2 \%$ ), редкая с повторяемостью от 1 раза в 50 лет до 1 раза в 100 лет (обеспеченность от 1 до $2 \%$ ), очень редкая с повторяемостью реже 1 раза в 100 лет (обеспеченность менее $1 \%$ ).

Буквами на карте обозначен генетический тип селя (гляциальный или дождевой) и состав селя (грязекаменный, грязевый, наносоводный).

На карте выделены прорывоопасные приледниковые озера с объемом воды от 10 до 100 и более 100 тыс. м ${ }^{3}$, которые могут быть источниками формирования прорывных гляциальных селей 2 и 1 категорий.

На карте также обозначены крупные селевые врезы в рыхлообломочных отложениях, являющиеся поставщиками твердого материала для дождевых и гляциальных селей.

Для прорывных гляциальных селей рассчитано время добегания селя в случае прорыва озера до объектов, расположенных по пути движения. Это время, выраженное в минутах, вынесено на карту.

На карте также показаны селезащитные сооружения: останавливающие и направляющие дамбы, сквозные решетчатые дамбы и сетчатые барьеры, укрепленные русла рек.

Для оценки селевых явлений при отсутствии количественных характеристик, предложено деление их на четыре категории по качественным признакам.

К первой категории отнесены очень крупные грязекаменные селевые потоки, которые характеризуются значительными расходами, обеспечивающими их прохождение на значительное расстояние (вплоть до выхода из гор), большой разрушительной силой. Ливневые сели первой категории возникают, как правило, благодаря формированию одновременно в нескольких селевых очагах селевого бассейна, вносящих одновременно или последовательно вклад в развитие селевых процессов в русле основной реки или в одном, но крупном селевом очаге (селевом врезе). Гляциальные сели первой категории формируются вследствие опорожнения крупных ледниково-моренных водоемов с большими значениями расходов прорывных паводков. Объем таких селей - более 1 млн м ${ }^{3}$, расходы - более $1000 \mathrm{~m}^{3} / \mathrm{c}$, скорость - более $10 \mathrm{~m} / \mathrm{c}$, высота валов - более 10 м, размер переносимых валунов - более $3 \mathrm{~m}$.

Ко второй категории относятся крупные грязекаменные потоки, проходящие значительные расстояния по руслу основной реки. Их объем - 1001000 тыс. м $^{3}$, расходы - 100-1000 м $3 /$ с, скорость - 510 м/с, высота валов - 5-10 м, размер переносимых валунов - 1-3 м. 